\title{
The Effect of Residents' Attitude toward Tourism on their Pro-Tourism Behaviour: A Case Study of Hua-Hin Prachubkirikhan
}

\author{
Noppanon Homsud \\ Department of Marketing, \\ Faculty of Management Science, \\ Silpakorn University
}

Doi: $10.1515 / m j s s-2017-0050$

\begin{abstract}
This study focused on the impact of attitude toward tourism on pro-tourism behaviour. The social exchange theory and theory of reasoned action were used to support this model. This study constructed a model for testing the relationship among welcome tourists behaviour, perceived local economy, personal benefit, attitude toward tourism, and pro-tourism behaviour. Empirical testing was used for observing the effect of the model. The sample comprised 408 people from Hua-hin Prachubkirikhan, who were selected by convenience sampling. The research instrument was a questionnaire that was divided into the following 4 parts: general data, perceived tourism impact (welcome tourists behaviour, perceived local economy, and personal benefit), attitude toward tourism, and pro-tourism behaviour. Statistical analysis methods included frequency, percentage, mean, standard deviation, and structural equation modelling. All the hypotheses were supported, indicating a significant positive effect of attitude toward tourism on pro-tourism behavior.
\end{abstract}

Keywords: Attitude toward tourism, Pro-tourism behaviour, Thailand, Residents' effect

\section{Introduction}

The weakening of old-fashioned industries such as agriculture, farming, pottery, fishery, cultivation, or handicraft has led many countryside societies to seek substitute economic systems for earning through tourism to reinforce the strength of community development. Community-based tourism has become a possible choice for developing tourism in traditional rural areas to achieve economic benefits for local residents. However, the expansion of sustainable tourism is problematic if the residents in the area do not support or contribute to activities, evidenced by behaviours such as not welcoming tourists or cheating them. A government agency that plans to use tourism as an alternative way to support its economic development must improve sustainable tourism to meet the requirements, attitudes, and demands of its inhabitants (Lee, 2013).

The theory of reasoned action is an accepted theory on attitudes and predicted behaviours (Ajzen and Fishbein, 1980). This theory explains that intentions and behaviours are a function of the following three basic determinants: attitude toward the behaviour, subjective norm, and perceived behavioural control (Ajzen, 2010). The social exchange theory, developed by Homans (1958), Thibaut and Kelley (1959), and Blau (1964), is another theory that explains the effect of attitudes on predicted behaviour. The social exchange theory, stemming from social psychology, emphasises the perceptions of costs and benefits and their consequences to satisfaction. Assessment is a significant section of social exchange, and it provides a standard against which all relationships are evaluated. Comparative values are personal and subjective, and they differ across individuals and groups (Ward and Berno, 2011). With reference to tourism, the social exchange 
theory suggests that individuals' attitudes towards tourism and their support for development may be influenced by the consequences of tourism for themselves and their communities (Andereck, Valentine, Knopf, and Vogt, 2005)

Hua-Hin, which has a population of 95,769, is one of district in Prachubkirikhan Province. Hua Hin is one of the most well-known tourist destinations among Thai tourists and visitors, partly because its tourism has been promoted through various activities such as regattas, golf tournaments, seminars, jazz music festivals, etc. Besides, Hua Hin is a place of all-year-long tourist activities. For example, visitors can swim in the sea even in the monsoon because the wind is not so strong. Visitors can visit Hua Hin very easily as it is only 180 kilometres away, on the south, from Bangkok, the capital of Thailand, and it takes only 2 hours to reach Hua Hin from Bangkok (Boonmeeseesanga, 2013).

\section{Review Literature}

\subsection{Pro-Tourism Behaviour and Attitude toward Tourism}

According to the social exchange theory, residents will support any activities tourism if they have a good attitude to tourism. Based on this theory, if the residents recognize that they will receive advantages from tourism without suffering costs, they will prefer to contribute to and participate in community-based tourism development (Jurowski, Uysal, and Williams, 1997). Many previous studies based on the social exchange theory have reported that if respondents perceive benefits, they are significantly and positively likely to support tourism development. For instance, Nunkoo and Ramkissoon (2011) studied this topic in Grand-baie, Mauritius; Choi and Murray (2010) studied it in Texas, USA; Nicholas, Thapa, and Ko (2009) studied it in Soufriere, a small town on the southwestern coast of the island of St. Lucia in the Caribbean; Kaltenborn, Andersen, Nellemann, Bjerke, and Thrane (2008) studied it in Øyer and Vestre Slidre, in Southeast Norway; and OviedoGarcía, Castellano-Verdugo, and Martín-Ruiz (2008) studied it in Santiponce, a small community in southern Spain. These findings suggest that residents in all contexts from both developed and developing countries tend to support tourism if they have a good attitude towards the same.

\subsection{Welcome Tourists Behaviour, Perceived Local Economy, and Personal Benefit}

Ribeiro, Pinto, Silva, and Woosnam (2017) divided the antecedents of attitude and pro-tourism behaviour into 3 factors; namely, welcome tourists behaviour, perceived local economy, and personal benefit.

Woosnam and Norman (2010) proposed the emotional solidarity scale to explain the relationship between residents and tourists. The scale consists of three factors; sympathetic understanding, welcoming visitors, and emotional closeness. However, many researches such as Woosnam (2011), and Woosnam and Aleshinloye (2013) used only welcoming visitors as a factor to measure emotional solidarity scale.

Tourism also helps the economic development of the community. It brings in a major percentage of the community's income. It also creates jobs for the local residents and provides opportunities for investment in infrastructure such as roads, rail, medical, and education. Moreover, it can act as an incentive to create a place to preserve and regenerate urban and wildlife areas, and promotes international links in the medium to long term. Stylidis and Terzidou (2014), and Gursoy, Chi, and Dyer (2010) found that the perceived local economy can affect the attitude toward tourism, while Dyer, Gursoy, Sharma, and Carter (2007) found that perceived local economy can affect the support for tourism, which implies pro-tourism behaviour.

Tourism can generate benefits for residents both directly and indirectly, such as by improving their quality of life or creating jobs for residents. Nunkoo and So (2016); Vargas-Sanchez, Valle, Mendes, and Silva (2015); and Boley, McGehee, Perdue, and Long (2014) found that residents who derive personal benefits from tourism have a more positive attitude toward it as compared to others. Moreover, Boley, McGehee, Perdue, and Long (2014), and McGehee and Andereck (2004) found that residents who derive personal benefits support tourism more than others do, which 
implies pro-tourism behaviour.

Based on the above discussion, the following 7 hypotheses were proposed:

$\mathrm{H} 1$ :Residents' welcome tourist behaviour has a positive effect on their attitude toward tourism. $\mathrm{H} 2$ :Residents' perceived local economy has a positive effect on their attitude toward tourism.

H3:Resident's perceived personal benefit has a positive effect on their attitude toward tourism. $\mathrm{H} 4$ :Residents' welcome tourist behaviour has a positive effect on their pro-tourism behaviour. H5:Residents' perceived local economy has a positive effect on their pro-tourism behaviour. H6:Resident's perceived personal benefit has a positive effect on their pro-tourism behaviour. $\mathrm{H} 7$ :Resident's attitude toward tourism has a positive effect on their pro-tourism behaviour.

\section{Research Methodology}

The target population in this study was the permanent residents of Hua-Hin, Prachubkirikhan (being a resident of Hua-Hin, Prachubkirikhan for more than one year) who were 20 years old or older. A sample size of at least 300 respondents was targeted based on the requirements of Structural Equation Modelling (SEM) for a model with less than 7 constructs (Hair, Black, Babin, and Anderson, 2010). The sample was selected by convenience sampling and the data were collected using a Thai language questionnaire by an undergraduate student. The data were collected from one person in each family. The final sample comprised 408 individuals.

The Thai language questionnaire comprised four main sections. The first section pertained to general data, including gender, age, occupation, education level, household income, number of members in the family, being engaged in work related to tourism, and number of years of residence in Hua-Hin. The second part measured the perceived impact of tourism (welcome tourists behaviour, perceived local economy, and personal benefit), using a Likert-type scale ( 1 = strongly disagree to 5 = strongly agree). The 12 attributes to measure welcome tourists behaviour, perceived local economy, and personal benefit were adapted from Choi and Sirikaya (2005), Wang and Pfister (2008), and Woosnam and Norman (2010). The third part measured attitude toward tourism using a Likert-type scale $(1=$ strongly disagree to $5=$ strongly agree), and it comprised 6 attributes adapted from Nunkoo and Gursoy (2012). The last part measured pro-tourism behaviour. The four attributes were adapted from Valle, Guerreiro, Mendes, and Silva (2011).

For testing the reliability and validity of the questionnaire, it was evaluated by three professionals in tourism. Having received some recommendations on the validity, each question was cautiously selected in terms of an Index of Item Objective Congruence (IOC) of more than 0.5. A pilot test was conducted with 30 Hua-Hin residents. Overall, the questionnaire's Cronbach's coefficient alpha was 0.877 . As the alpha was closer to 1 , the questionnaire was considered to exhibit high internal consistency (Cronbach, 1951). Therefore, the questionnaire was used with the final samples.

After checking for missing values, descriptive statistics were computed for the general data. Subsequently, the relationships among welcome tourists behaviour, perceived local economy, personal benefit, attitude toward tourism, and pro-tourism behaviour were tested using a Confirmatory Factor Analysis (CFA). Structural equation modelling (SEM) was used to examine the effect of welcome tourists' behaviour, perceived local economy, and personal benefit on attitude toward tourism; and that of welcome tourists' behaviour, perceived local economy, personal benefit to pro-tourism behaviour; and attitude toward tourism on pro-tourism behaviour. All analyses were conducted using IBM SPSS Statistics 22 and IBM SPSS AMOS22 trial version. Model fit was assessed using the following six indicators: $x^{2} / d f$, goodness of fit index (GFI), adjusted goodness of fit index (AGFI), root mean square error of approximation (RMSEA), comparative fit index (CFI), and standardised root mean square residual (SRMR).

\section{Results}

1. Most of the participants of this study were female (69.61\%), were aged $31-40$ years (31.13\%), had a bachelor's degree (76.23\%), had a monthly income of 30,001-50,000 THB (about 875-1460 USD) $(40.44 \%)$, had 4 members in the family $(35.30 \%)$, were not engaged in work related to 
tourism (56.62\%), and had resided at Hua-Hin for more than 5 years $(63.73 \%)$ (see Table 1).

Table 1: General Data of the Sample

\begin{tabular}{|c|c|c|c|}
\hline Demographic & & $\begin{array}{c}\text { Frequency } \\
(\mathrm{N}=400)\end{array}$ & Percentage \\
\hline Gender & $\begin{array}{l}\text { Female } \\
\text { Male }\end{array}$ & $\begin{array}{l}284 \\
124\end{array}$ & $\begin{array}{l}69.61 \% \\
30.39 \%\end{array}$ \\
\hline Age & $\begin{array}{l}21-30 \text { years old } \\
31-40 \text { years old } \\
41-50 \text { years old } \\
51-60 \text { years old } \\
\text { More than } 60 \text { years old }\end{array}$ & $\begin{array}{c}77 \\
127 \\
88 \\
65 \\
51\end{array}$ & $\begin{array}{l}18.87 \% \\
31.13 \% \\
21.57 \% \\
15.93 \% \\
12.50 \%\end{array}$ \\
\hline Educational Level & $\begin{array}{l}\text { Lower Bachelor's Degree } \\
\text { Bachelor's Degree } \\
\text { Upper Bachelor's Degree }\end{array}$ & $\begin{array}{c}37 \\
311 \\
60\end{array}$ & $\begin{array}{c}9.07 \% \\
76.23 \% \\
14.70 \%\end{array}$ \\
\hline Monthly Income & $\begin{array}{l}\text { Lower than } 20,000 \text { THB } \\
20,000-30,000 \text { THB } \\
30,001-50,000 \text { THB } \\
50,001-100,000 \text { THB } \\
\text { More than } 100,000 \text { THB }\end{array}$ & $\begin{array}{c}60 \\
72 \\
165 \\
89 \\
22\end{array}$ & $\begin{array}{c}14.71 \% \\
17.65 \% \\
40.44 \% \\
21.81 \% \\
5.39 \%\end{array}$ \\
\hline Number of People in Family & $\begin{array}{l}\text { Living alone } \\
2 \text { People } \\
3 \text { People } \\
4 \text { People } \\
5 \text { People } \\
\text { More than } 5 \text { People }\end{array}$ & $\begin{array}{c}22 \\
84 \\
95 \\
144 \\
49 \\
14\end{array}$ & $\begin{array}{c}5.39 \% \\
20.59 \% \\
23.29 \% \\
35.30 \% \\
12.00 \% \\
3.43 \%\end{array}$ \\
\hline Association with Tourism & $\begin{array}{l}\text { Yes } \\
\text { No }\end{array}$ & $\begin{array}{l}177 \\
231\end{array}$ & $\begin{array}{l}43.38 \% \\
56.62 \%\end{array}$ \\
\hline Length stay in Hua-Hin & $\begin{array}{l}1-2 \text { years } \\
3-5 \text { years } \\
\text { More than } 5 \text { years }\end{array}$ & $\begin{array}{c}51 \\
97 \\
260\end{array}$ & $\begin{array}{l}12.50 \% \\
23.77 \% \\
63.73 \%\end{array}$ \\
\hline
\end{tabular}

2. The next phase of analysis examined the measurement model using CFA with the maximum likelihood estimation method. Additionally, the reliability and validity of the questionnaire was assessed using composite reliability (CR). A CR score higher than 0.70 is considered to indicate high reliability (Nunnally and Bernstein, 1994). Further, factor loadings and Average Variance Extracted (AVE) were used for validity measurement. Table 2 shows that all the factor loadings were above 0.5 (Hair, Black, Babin, and Anderson, 2010). The AVE values have also been presented in Table 2. The initial measurement model had CMIN/DF $=2.786, \mathrm{CFI}=0.905, \mathrm{GFI}=$ $0.868, \mathrm{RMR}=0.026$, and RMSEA $=0.066$, while the adjusted model had CMIN/DF $=0.938, \mathrm{CFI}=$ $1.000, \mathrm{GFI}=0.964, \mathrm{RMR}=0.015$, and RMSEA $=0.000$, which were acceptable values (Hair, Black, Babin, and Anderson, 2010).

Table 2: The Measurement Model

\begin{tabular}{|c|c|c|c|c|c|}
\hline Variables & Loading & Mean & S.D. & Skew & Kurt \\
\hline \multicolumn{6}{|c|}{ Welcome Tourists Behaviour (CR $=0.835$ and AVE $=0.578$ ) } \\
\hline The community benefit from having tourists & 0.921 & 4.36 & 0.57 & -0.39 & 0.21 \\
\hline Pride in having tourists come to the city & 0.958 & 4.39 & 0.58 & -0.52 & 0.20 \\
\hline Treat all tourists fairly & 0.525 & 4.32 & 0.60 & -0.43 & 0.08 \\
\hline Appreciate tourists' contributions to the city & 0.521 & 4.36 & 0.61 & -0.47 & -0.29 \\
\hline
\end{tabular}




\begin{tabular}{|c|c|c|c|c|c|}
\hline Variables & Loading & Mean & S.D. & Skew & Kurt \\
\hline \multicolumn{6}{|l|}{ Perceived Local Economy $(C R=0.778$ and AVE $=0.474)$} \\
\hline Public agency should create more jobs in the city & 0.668 & 4.35 & 0.71 & -0.86 & 0.66 \\
\hline Willing to pay more expenses if the economy in the city is growing & 0.719 & 4.37 & 0.72 & -0.83 & -0.05 \\
\hline Living standard is increasing because of tourism & 0.702 & 4.35 & 0.69 & -0.72 & -0.08 \\
\hline Tourism is increasing the job opportunities for local people & 0.644 & 4.35 & 0.73 & -0.80 & -0.15 \\
\hline \multicolumn{6}{|l|}{ Personal Benefit $(C R=0.735$ and AVE $=0.410)$} \\
\hline Personal economic factors depend on tourism & 0.692 & 4.35 & 0.69 & -0.76 & 0.14 \\
\hline Tourists help to pay taxes indirectly & 0.580 & 4.40 & 0.73 & -1.01 & 0.43 \\
\hline Household economic factors will be better by receiving more tourists & 0.637 & 4.40 & 0.72 & -0.93 & 0.12 \\
\hline Local people get economic benefits from tourism & 0.649 & 4.36 & 0.61 & -0.99 & 0.83 \\
\hline \multicolumn{6}{|l|}{ Attitude toward Tourism (CR $=0.865$ and AVE $=0.515)$} \\
\hline Create more jobs in the city & 0.693 & 4.40 & 0.61 & -0.50 & -0.63 \\
\hline Attract more investment to the city & 0.715 & 4.42 & 0.62 & -0.58 & -0.59 \\
\hline Lead to improvement of infrastructure & 0.736 & 4.41 & 0.60 & -0.44 & -0.67 \\
\hline Increase of cost of living & 0.684 & 4.42 & 0.59 & -0.48 & -0.66 \\
\hline Loss of traditional living & 0.732 & 4.46 & 0.58 & -0.49 & -0.71 \\
\hline Damage to natural resources & 0.747 & 4.42 & 0.61 & -0.55 & -0.60 \\
\hline \multicolumn{6}{|l|}{ Pro-tourism Behaviour $(C R=0.758$ and $A V E=0.439)$} \\
\hline Willingness to protect natural resources for tourism & 0.664 & 4.37 & 0.64 & -0.49 & -0.66 \\
\hline Willingness to provide information to tourists & 0.708 & 4.37 & 0.67 & -0.57 & -0.70 \\
\hline Willingness to promote the city as a tourist destination & 0.620 & 4.37 & 0.67 & -0.61 & -0.70 \\
\hline Willingness to accept inconvenient situations to derive $b$ & 0.658 & 4.34 & 0.70 & -0.58 & -0.81 \\
\hline
\end{tabular}

3. The hypothesized relationships among the study's constructs were tested in the structural model with maximum likelihood estimation. The results indicated the adequacy of the structural model, with $x^{2}=594.362($ sig. $=0.000), \mathrm{CMIN} / \mathrm{DF}=2.942, \mathrm{CFI}=0.895, \mathrm{GFI}=0.859, \mathrm{RMR}=0.038$, and RMSEA $=0.069$, and of the adjusted model, with $X^{2}=222.849$ (sig. $\left.=0.042\right)$ CMIN/DF $=1.185, C F I$ $=0.991, \mathrm{GFI}=0.954, \mathrm{RMR}=0.029$, and RMSEA $=0.021$ (Hair, Black, Babin, and Anderson, 2010).

These findings indicate that the hypothesized model had a good fit with the empirical data. As seen in Table 3, standardized coefficients of the seven hypothesized relationships were significant in the expected direction. Table 4-6 show the direct, indirect, and total effects of each relationship. Moreover, Figure 1 shows the adjusted calculated model, indicating that the seven hypothesized relationships were significant as expected.

Table 3: Standardized Coefficients for all the Study Hypotheses

\begin{tabular}{lllllc}
\hline Hypothesis Relationship & & & S.Est. & t-stat \\
\hline H1: Residents' welcome tourist behaviour & $\rightarrow$ & Resident's attitude toward tourism & 0.216 & $3.307^{* * *}$ \\
H2: Residents' perceived local economy & $\rightarrow$ & Resident's attitude toward tourism & 0.379 & $6.231^{* * *}$ \\
H3: Resident's perceived personal benefit & $\rightarrow$ & Resident's attitude toward tourism & 0.321 & $5.360^{* * *}$ \\
H4: Residents' welcome tourist behaviour & $\rightarrow$ & Resident's pro-tourism behaviour & 0.227 & $3.123^{\star *}$ \\
H5: Residents' perceived local economy & $\rightarrow$ & Resident's pro-tourism behaviour & 0.200 & $3.084^{* *}$ \\
H6: Resident's perceived personal benefit & $\rightarrow$ & Resident's pro-tourism behaviour & 0.143 & $2.255^{*}$ \\
H7: Resident's attitude toward tourism & $\rightarrow$ & Resident's pro-tourism behaviour & 0.239 & $2.913^{* *}$ \\
\hline ***
\end{tabular}

Table 4: Total Effects

\begin{tabular}{lcc}
\hline & Attitude & Pro-tourism \\
\hline Welcome Tourism & 0.216 & 0.279 \\
Local Economy & 0.379 & 0.291 \\
Personal Benefit & 0.321 & 0.219 \\
Attitude & & 0.239 \\
\hline
\end{tabular}


Table 5: Direct Effect

\begin{tabular}{lcc}
\hline & Attitude & Pro-tourism \\
\hline Welcome Tourism & 0.216 & 0.227 \\
Local Economy & 0.379 & 0.200 \\
Personal Benefit & 0.321 & 0.143 \\
Attitude & & 0.239 \\
\hline
\end{tabular}

Table 6: Indirect Effect

\begin{tabular}{lcc}
\hline & Attitude & Pro-tourism \\
\hline Welcome Tourism & 0.000 & 0.052 \\
Local Economy & 0.000 & 0.091 \\
Personal Benefit & 0.000 & 0.077 \\
Attitude & & 0.000 \\
\hline
\end{tabular}

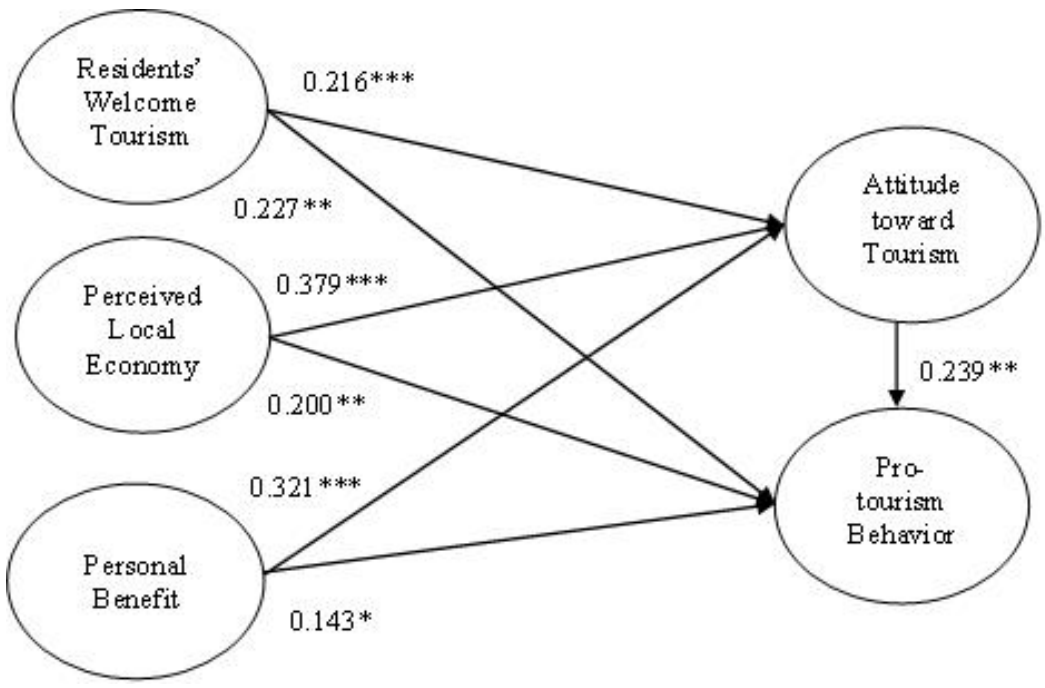

Figure 1: The Adjusted Calculation Model

\section{Conclusion, Implication, and Recommendation}

This study revealed that attitude toward tourism affected pro-tourism behaviour positively. It was also shown that welcome tourists behaviour, perceived local economy, and personal benefit affected attitude toward tourism positively. Moreover, welcome tourists behaviour, perceived local economy, and personal benefit affected pro-tourism behaviour positively.

The present finding that attitude toward tourism affected pro-tourism behaviour supports the findings of the studies conducted by Nunkoo and Ramkissoon (2011), Choi and Murray (2010), Nicholas, Thapa, and Ko (2009), Kaltenborn, Andersen, Nellemann, Bjerke, and Thrane (2008), and viedo-García, Castellano-Verdugo, and Martín-Ruiz (2008). The result that welcome tourists behaviour affected attitude toward tourism and pro-tourism behaviour supported the findings of the studies by Woosnam (2011) and Woosnam and Aleshinloye (2013). Similarly, in keeping with the findings of Stylidis and Terzidou (2014), Gursoy, Chi, and Dyer (2010), and Dyer, Gursoy, Sharma, and Carter (2007), the present study revealed that perceived local economy affected both attitude toward tourism and pro-tourism behaviour. Finally, the present results confirm the findings of 
Nunkoo and So (2016), Vargas-Sanchez, Valle, Mendes, and Silva (2015), Boley, McGehee, Perdue, and Long (2014), and McGehee and Andereck (2004) that personal benefit affects attitude toward tourism and pro-tourism behaviour positively.

The present results extend body of knowledge on tourism, especially on resident tourism. It also supports the use of the social exchange theory and theory of reason action to explain residents' support for tourism. In this study, attitude toward tourism was found to mediate the relationship between pro-tourism behaviour and other factors. This finding suggests that support from residents can be improved by improving their attitudes toward tourism. The standardized coefficients revealed that improving residents' perception of the economic benefits of tourism to the local economy and the personal benefits of the same can help improve their attitude toward tourism and increase their pro-tourism behaviour.

Since resident support is important for community tourism development, government agencies can use the present results to emphasise on the attitudes of residents, such as by providing information about the benefits of tourism for residents, providing them opportunities to participate in tourism projects, or designing events that both residents and tourists can participate in together.

There are many limitations in this study. Firstly, the study of attitudes should address both negative and positive attitudes, as done in the study by Ribeiro, Pinto, Silva, and Woosnam (2017). Second, this study was conducted in Hua-Hin, which is a prosperous city in Thailand. Future studies should be conducted in impoverished cities. Finally, the concepts of individualism and collectivism should be applied to this study because residents with different lifestyles or life attitudes could exhibit different attitudes and behaviour pertaining to tourism as well.

\section{References}

Ajzen, I. (2005). Attitudes, personality, and behavior. ( $2^{\text {nd }}$ ed.). Berkshire: Open University Press.

Ajzen, I., \& Fishbein, M. (1980). Understanding attitudes and predicting social behavior. New Jersey: PrenticeHall.

Andereck, K. L., Valentine, K. M., Knopf, R. C., \& Vogt, C. A. (2005). Residents' perceptions of community tourism impacts. Annals of Tourism Research, 32(4), 1056-1076.

Blau, P. M. (1964). Exchange and power in social life. New York: Wiley.

Boley, B. B., McGehee, N. G., Perdue, R. R., \& Long, P. (2014). Empowerment and resident attitudes toward tourism: Strengthening the theoretical foundation through a Weberian lens. Annals of Tourism Research, $49,33-50$.

Boonmeeseesanga, M. (2013). The identity construction of destination branding Amphoe Hua - Hin, Changwat Prachuap Khiri Khan amongst young tourists' perspective. Veridian E-Journal, 6(1), 548-560.

Choi, H. C., \& Murray, I. (2010). Resident attitudes toward sustainable community tourism. Journal of Sustainable Tourism, 18(4), 575-594.

Choi, H. S., \& Sirikaya, E. (2005). Measuring residents' attitudes toward sustainable tourism: Development of sustainable tourism attitude scale. Journal of Travel Research, 43(4), 380-394.

Cronbach, L. J. (1951). Coefficient alpha and the internal structure of tests. Psychometrika, 16(3), 297-334.

Dyer, P., Gursoy, D., Sharma, B., \& Carter, J. (2007). Structural modelling of resident perceptions of tourism and associated development on the Sunshine Coast, Australia. Tourism Management, 28(2), 409-422.

Gursoy, D., Chi, C. G., \& Dyer, P. (2010). Locals' Attitudes toward Mass and Alternative Tourism: The Case of Sunshine Coast, Australia. Journal of Travel Research, 49(3), 381-394.

Hair, J. F., Black, W. C., Babin, B. J., \& Anderson, R. E. (2010). Multivariate Data Analysis. New Jersey: Prentice Hall.

Homans, G. C. (1958). Social behavior as exchange. American Journal of Sociology, 63(6), 597-606.

Jurowski, C., Uysal M., \& Williams, D. R. (1997). A theoretical analysis of host community resident reactions to tourism. Journal of Travel Research, 36(2), 3-11.

Kaltenborn, B. P., Andersen, O., Nellemann, C., Bjerke, T., \& Thrane, C. (2008). Resident attitudes towards mountain second-home tourism development in Norway: the effects of environmental attitudes. Journal of Sustainable Tourism, 16(6), 664-680.

Lee, T. H. (2013). Influence analysis of community resident support for sustainable tourism development. Tourism Management, 34, 37-46.

McGehee, N. G., \& Andereck, K. L. (2004). Factors predicting rural residents' support of tourism. Journal of Travel Research, 43(2), 131-140.

Nicholas, L. N., Thapa, B., \& Ko, Y. J. (2009). Residents' perspectives of a world heritage site: the Pitons management area, St. Lucia. Annals of Tourism Research, 36(3), 390-412. 
Nunkoo, R., \& Gursoy, D. (2012). Residents' support for tourism: An identity perspective. Annals of Tourism Research, 39(1), 243-268.

Nunkoo, R., \& Ramkissoon, H. (2011). Residents' satisfaction with community attributes and support for tourism. Journal of Hospitality \& Tourism Research, 35(2), 171-190.

Nunkoo, R., \& So, K. K. F. (2016). Residents' support of tourism: Testing alternative structural models. Journal of Travel Research, 55(7), 847-861.

Nunnally, J. C., \& Bernstein, I. (1994). Psychometric Theory. New York: McGraw-Hill, 1994.

Oviedo-Garcia, M., Castellanos-Vergudo, M., \& Martin-Ruiz, D. (2008). Gaining residents' support for tourism and planning. International Journal of Tourism Research, 10(2), 95-109.

Ribeiro, M. A., Pinto, P., Silva, J. A., \& Woosnam, K. M. (2017). Residents' attitudes and the adoption of protourism behaviours: The case of developing island countries. Tourism Management, 61, 523-537.

Stylidis, D., \& Terzidou, M. (2014). Tourism and the economic crisis in Kavala, Greece. Annals of Tourism Research, 44, 210-226.

Thibaut, J. W., \& Kelley, H. H. (1959). The social psychology of groups. New York: Wiley.

Valle, P. O., Guerreiro, M., Mendes, J., \& Silva, J. A. (2011). The cultural offer as a tourist product in coastal destinations: The Case of Algarve, Portugal. Tourism and Hospitality Research, 11(4), 233-247.

Vargas-Sanchez, A., Valle, P. O. D., Mendes, J. D. C., \& Silva, J. A. (2015). Residents' attitude and level of destination development: An international comparison. Tourism Management, 48, 199-210.

Wang, Y., \& Pfister, R. E. (2008). Residents' attitudes toward tourism and perceived personal benefits in a rural community. Journal of Travel Research, 47(1), 84-93.

Ward, C., \& Berno, T. (2011). Beyond social exchange theory: attitudes toward tourists. Annals of Tourism Research, 38(4), 1556-1569.

Woosnam, K. M. (2011). Testing a model of Durkheim's theory of emotional solidarity among residents of a tourism community. Journal of Travel Research, 50(5), 546-558.

Woosnam, K. M., \& Aleshinloye, K. D. (2013). Can tourist experience emotional solidarity with residents? Testing Durkheim's model from a new perspective. Journal of Travel Research, 52(4), 494-505.

Woosnam, K. M., \& Norman, W. C. (2010). Measuring residents' emotional solidarity with tourists: Scale development of Durkheim's theoretical constructs. Journal of Travel Research, 49(3), 365-380. 